Article

\title{
Digital Customer Experience Mapping in Russian Premium Banking
}

\author{
Galina Timokhina ${ }^{1, *}$, Lyubov Prokopova ${ }^{1,2}$, Yuri Gribanov ${ }^{2}$, Stanislav Zaitsev ${ }^{2}$, Natalia Ivashkova ${ }^{1}$, \\ Roman Sidorchuk ${ }^{1}$, Irina Skorobogatykh ${ }^{1}$, Anatoly Shishkin ${ }^{1}$ and Zhanna Musatova ${ }^{1}$
}

1 Marketing Department, Marketing Faculty, Plekhanov Russian University of Economics, Stremyanny Lane, 36, 117997 Moscow, Russia; researcher-prokopova@inbox.ru (L.P.); nataliaivashkova@mail.ru (N.I.); professor_sidorchuk@mail.ru (R.S.); irina.i.skorobogatykh@yandex.ru (I.S.); shishkin_1971@internet.ru (A.S.); zhannatmusatova@yandex.ru (Z.M.)

2 Russian Research Company Frank RG, Leningradsky Avenue, 37, 125167 Moscow, Russia; yuri.gribanov@rambler.ru (Y.G.); stanislavzaitsev7@gmail.com (S.Z.)

* Correspondence: galinatimokhina@bk.ru

\section{check for} updates

Citation: Timokhina, Galina, Lyubov Prokopova, Yuri Gribanov, Stanislav Zaitsev, Natalia Ivashkova, Roman Sidorchuk, Irina Skorobogatykh, Anatoly Shishkin, and Zhanna Musatova. 2021. Digital Customer Experience Mapping in Russian Premium Banking. Economies 9: 108. https://doi.org/10.3390/

economies 9030108

Academic Editor: Sajid Anwar

Received: 2 June 2021

Accepted: 30 July 2021

Published: 5 August 2021

Publisher's Note: MDPI stays neutral with regard to jurisdictional claims in published maps and institutional affiliations.

Copyright: (c) 2021 by the authors. Licensee MDPI, Basel, Switzerland. This article is an open access article distributed under the terms and conditions of the Creative Commons Attribution (CC BY) license (https:// creativecommons.org/licenses/by/ $4.0 /)$.

\begin{abstract}
The purpose of this study is to identify, in an era of extensive digitalization, the major opportunities and threats that influence the experiences of digital premium banking customers at key stages of their banking interactions. This study's conceptual research model combines the content of online questionnaires, completed by a representative sample of 3629 customers, in-depth interviews with heads of premium banking departments, and an audit of customer experiences conducted via Mystery Shopping in 13 Russian banks. The authors formulate four research hypotheses, substantiated by the empirical data and highlight key barriers preventing premium banks from effective digital interactions with their customers. Key opportunities for improving customer experiences are also identified. The theoretical contribution of the research includes the adaptation of an axiological approach to studying digital customers in premium banking. Practical contributions include the Premium Digital Customer Experience Map, designed by the authors as a ready-made tool for planning and improving premium banking services and a tool for performance comparison between competing banks. This study also discusses the authors' definition of a "digital customer". It presents a new approach to the Mystery Shopping methodology, including the recruitment of Mystery Shoppers following the three premium banking customer portraits: "saver", "spender", and "saver-spender".
\end{abstract}

Keywords: digital customer; premium banking; key phases interactions; improving customer experience; banking digitalization; experience mapping

\section{Introduction}

Expert interviews with 12 heads of premium banking departments in the largest retail banks in Russia have revealed two key areas for premium banking development: the digitalization of banking services and intra-banking processes, and customer experience improvement (Frank 2020). Both areas of development are highly relevant to the premium banking market (Frank 2020). Premium customers with financial assets from RUB 4 to 60 million (from USD 50,000 to USD 800,000, according to the market segmentation in premium banking in Russia) have found that their assets have become increasingly digital as well as very demanding. In addition to a high-quality banking product, these customers require high-quality customized professional service and convenience at every stage of interaction with the bank (Timokhina 2019; Timokhina and Kapustina 2017; Park and Choi 2019; and Frank 2020). Premium customers place their capital in three or four banks on average, and a negative customer experience may influence their decisions about how their capital is allocated across these banks. 
In the context of intense competition in premium banking, it is essential to study customer experiences systematically and make decisions that meet customer needs (Dew and Allen 2020; and Fader and Thoms 2021). It is particularly important to find the right balance of offline and online services that provide customers with comfortable, straightforward, and seamless experiences with their banks (Frank 2020; Vatolkina et al. 2020; and Barmuta et al. 2019).

We define "digital customer" as a member of the exchange process of knowledge, skills, and abilities required for the safe and successful utilization of digital technologies and Internet resources, which enables them to purchase goods and services that meet their needs, benefit them financially, and match their values. The decision-making process of a digital customer involves, to a large extend, intellectual reasoning (Komulainen and Saraniemi 2019; and Shaikh et al. 2020). The intellectual reasoning of the digital customer includes information searches through digital devices, active use of social networks, carrying out digital financial transactions, online shopping, information storing, and critical thinking (Manivannan and Sarah JP 2018; Ding et al. 2021; and Asnawi and Setyaningsih 2021).

A premium digital customer relates to a premium banking customer who interacts with a bank online and offline. Premium customers prefer to contact the bank mainly through digital channels, such as desktop online banking platforms and mobile banking applications (Karsh and Abufara 2020). However, it remains important to have an option for comfortable offline engagement with a Relationship Manager (RM) if more complex issues cannot be resolved by self-service.

The purpose of this study is to identify priority opportunities and threats (barriers) that facilitate/prevent digital customers of premium banking from receiving positive experience/perception of experience at key stages of interaction with a bank in the era of extensive digitalization in banking, which improves the decision-making process in marketing management.

The objectives of the current research include:

- Analyzing premium digital customer experience following the main customer interaction scenarios in premium banking based on the Mystery Shopping technics;

- Detecting the main issues that complicate the selection process and further interaction with a premium bank;

- Identifying priorities leading to the improvement of premium digital customer experience;

- Visualizing the premium digital customer experience: creating a Premium Digital Customer Experience Map based on Mystery Shopping analysis results and making an illustrative comparison of two competing banks from the sample.

The originality of the study includes:

1. Studied and analyzed customer experience at key stages of interaction between a premium digital customer and a premium bank within the market of scarce disclosed data;

2. The authors proposed to systematize the values of a digital customer in premium banking that enabled an axiological approach to be applied to customer experience management in marketing and contributed largely to academic science;

3. The authors' definition of the term "digital customer", a new approach to the Mystery Shopping methodology in premium banking including the recruitment of Mystery Shoppers following the three premium banking customer portraits-saver, spender and saver-spender.

\section{Literary Analysis and Conceptual Framework}

The study of customer behavior transformation in the context of digitalization has become extremely relevant for various business sectors, especially service sectors, retailers, and banks (Naylor et al. 2008; Dholakia et al. 2010; Fang et al. 2014; Daoud et al. 2015; Voorveld et al. 2016; Ivashkova 2016; Lee and Lee 2020a, 2020b; Alam et al. 2021; and Cahyadi and Magda 2021). The researchers' main focuses concern the development and determination of a balanced combination between online and offline trade, including the 
identification the of good digital marketing technologies (Parise et al. 2016; Chylinski et al. 2020; Hickman et al. 2020; Frasquet-Deltoro et al. 2021; Rincón et al. 2021; and Pino et al. 2020). According to changes in the economy and technology, communications with customers are transformed from one-way customer relations, to then focus on longterm and bilateral relations and emphasizing a customization approach using online and offline channels of communication (Kotler et al. 2016; Ivashkova 2016). Trends in consumer behavior also change over the years. The factors influencing customer behavior in the modern digital economy include pricing policy, consulting, security, and service quality (Ieva and Ziliani 2018; Karpova et al. 2019; Szopiński 2016; Wang et al. 2021; and Shaikh et al. 2017). Customer experience is another influencing factor considered to be one of the most important (Stankevich 2017). There are new touchpoints in a rapidly changing digital environment which involve a whole new customer experience.

Many researchers contributed various studies containing a profound theoretical overview of the development of the term, "customer experience", conceptual models of the influence of customer experience on business results, the actual situation in various markets, as well as results of empirical studies which enable an assessment of the impact of customer experience and its components on customer loyalty (Berry et al. 2002; Sousa and Voss 2006; Gentile et al. 2007; Schwager and Meyer 2007; Naylor et al. 2008; Verhoef et al. 2009; Voss et al. 2009).

Digitalizing the economy and technology development introduces new potential customer touchpoints for companies with customers' experiences existing in online communities (Nohutlu et al. 2021; Marriott and Williams 2018; Weiber and Kollmann 1998; and Drummond et al. 2020). Customer Experience Management focuses on the current customer experience, emphasizing emotional experience at customer touchpoints (Rawson et al. 2005; Panteleeva et al. 2017; Grewal et al. 2003; Grohmann et al. 2007; Oyner and Kazakov 2019; and Solovieva et al. 2020). Researchers proposed diverse approaches and models for Customer Experience Management practices (Aoki et al. 2019; Arenkov et al. 2019; and Orlova et al. 2020). Along with generally accepted methods of measuring customer satisfaction and service quality levels, particularly SERVQUAL (Parasuraman et al. 1985, 1988, 2005; Tarantola et al. 2012; Voss et al. 2009), researchers proposed to exploit a new customer experience measuring tool-Customer Experience Quality (EXQ) (Klaus and Maklan 2007, 2013).

The banking sector has undergone one of the most substantial transformations as a result of digitalization. The significant transition of banking services into an online format has stimulated a growing interest in studying the banking customer experience around the globe (Laukkanen et al. 2008; Ozdemir and Trott 2009; Yoon 2010; Hickman et al. 2020; Nikumanesh and Albadvi 2014; Montazemi and Qahri-Saremi 2015; Shankar and Jebarajakirthy 2019; Sia et al. 2016; and Albashrawi and Motiwalla 2020). Several studies included analyses of influencing factors on the banking channels selection process (Lee and Lee 2020b; Timokhina 2019; Verhoef et al. 2007; Bawankule and Chandani 2020; and Shin et al. 2020). Different researchers focused on studying different variables. Crosscultural differences impacted Internet banking adoption patterns in different countries (Yuen 2013; Yuen et al. 2015). Nevertheless, based on an analysis of relevant sources, Szopiński (2016) highlighted the most common qualitative factors: the perceived usefulness of online banking, ease of use, and trust. Among the common quantitative factors are education, access to infrastructure, income, age, and gender.

The researchers revealed the impact of the digital banking customer experience, including utility, convenience, employee and customer engagement, and security, on customer satisfaction and intent to reuse banking services (Shin 2021). A correlation was noted between corporate sustainability and digitalization (Garzaro et al. 2021), the impact of interaction with customers, and social presence on the relationship between banks and customers, which influence brand perception, customer satisfaction and loyalty (Umans et al. 2018; Boateng 2019; Boonlertvanich 2019; Garzaro et al. 2021; and Payne et al. 2021).

The results of a study by a leading Hong Kong bank revealed the role of social capital (Chan et al. 2020). This paper presents a concept based on social capital theory to assess the 
moderating effect of social capital on the relationship between perceived relative advantage and the adoption of interactive electronic channels by premium customers in the banking industry. According to this theory, RMs are encouraged to identify common values and proper uses of language that will reinforce cognitive capital, relieving the need for highly detailed and technical product information.

Further attentive research on the cultural patterns of consumers of banking services is warranted (Zhang et al. 2018). The authors suggest that national culture may affect the acceptance of banking services, including electronic services. Despite globalization, understanding the cross-cultural differences between banking consumers in different countries requires special research. When private banks encountered the COVID-19 crisis, they were in a difficult starting position following the second year of declining profits. According to McKinsey's 2020 Private Banking Survey, European private banks face three new challenges: pressures on revenues and profits from the uncertainties brought about by the COVID-19 crisis, an acceleration in client demand for digital services, and a shift toward remote working (Azad et al. 2020). European experts believe that thanks to the strong trust built into the process of managing private capital and safeguarding wealth for many generations of premium customers, private banks in Europe can emerge from the COVID-19 crisis stronger.

As part of asset and wealth management, as well as the challenges of protecting customers from market risks that emerged in 2020, banks are redesigning their business processes to become more digitally oriented (Donati 2020). Among the trends in the development of communication of the European private banking, we can highlight these two points: firstly, the importance of the functioning of front offices, as customers want to understand the essence of the management of their capital to receive comprehensive consultations; and secondly, the clients tend to prefer multichannel interactions.

The BRICS countries' economies, representing $40 \%$ of the world population and $32 \%$ of its GDP, are a powerful force for the private banking industry's wealth creation. Still, they are all distinct markets with unique opportunities. Nevertheless, common problems and challenges in managing private capital for many banks are common to each of them. These include a demand for educating clients, increasing professionalism in investing; a trend to digital offerings; and interest in private equity and environmental, social, and governance criteria (Euromoney 2020). Private banking in the BRIGS countries is trying to find answers to important questions; for example, are clients looking to go global? This can be achieved by analyzing customer attitudes toward the current key trends in Europe and the US, such as sustainability, growing life expectancy, improvement of client experience, and the rising demand for wealth succession services.

The premium customer market is a special and important segment of the more affluent customer base in the banking industry. Customers are "relationship-managed" in being assigned a designated RM as their primary point of contact for all their banking and financial needs. Premium customers and their RMs are thus expected to co-create customer wealth and financial strength through these professional financial consultation services, making them collaborative partners with the bank (Vargo and Lusch 2004).

Banks have increasingly recognized the importance of delivering a positive customer experience as a key factor for building sustainable customer loyalty and achieving successful business results. The banking service perception has changed throughout all customer segments, with the most significant influence of digital transformation on affluent clientele. Several researchers proposed tools for measuring premium bank attractiveness for affluent customer segments through the comparative analysis of competitive banks (Lee and Lee 2020a, 2020b; and Ershova et al. 2021). Despite the relevance of customer experience studies in various industries, including banking, there is still a lack of research focusing on system construction for brand-customer touchpoints in the premium banking industry. The present study adds to this stream of research by examining the main interaction between a premium digital customer and retail banks in Russia to make connections across different stages of the communication process. 
The theoretical research framework of the current study relies on the Customer Experience Management concept that includes analyses of the customer experience at every stage of interaction with a brand to construct targeted customer emotions and impressions, and adjust and improve customer experience. The researchers Panteleeva et al. (2017); Lee and Lee (2020a); Hickman et al. (2020); and Hoehle et al. (2012) all emphasize that the Customer Experience Management concept is based specifically on the customer's touchpoints with a brand, with arising personal impressions that determine the brand's uniqueness separating it from its competitors. Customer Experience Management involves a decision-making process focused on improving customer emotions and impressions at every stage of the customer's journey. Thus, we hypothesize the following:

Hypothesis 1 (H1): The convenience of information searching on the bank's website (both for desktop and mobile versions) and the availability of various options for an initial meeting scheduling positively influences premium digital customer experience.

Digital banking channels have been actively developed in banking, with premium banking showing the highest level of digital infiltration among the customers. The premium digital customers become increasingly demanding for digital convenience and expect a high level of human communication, if inevitable on the customer's journey. It remains important to present an opportunity for the customer to select the service that better meets their needs.

Hypothesis 2 (H2): Premium digital customers still lack convenient locations and highly comfortable branches in premium banking.

Premium banks have been intensively investing in their premium branches networks to ensure a convenient location for the customers as well as high-class service inside the branches that includes a proper interaction with retail bank personnel at the entrance of a branch, allocation of the premium lounge in case a customer needs to wait, and a dedicated room/working office of the RM. However, there is still a lack of high-quality premium banking zones within the retail branches network. Rapid digitalization of banking services makes it questionable if premium banking still needs to continue to maintain offline service development.

Hypothesis 3 (H3): Digital customers receive a positive customer experience in premium banking if the RM demonstrates a high level of professional and communicational skills.

The priority opportunity for customer experience improvement relies upon the RM's role in connection with premium banking digitalization. As a result of growing opportunities for premium digital customers to independently collect and analyze any necessary information, they do not need a bank to receive a product description or assist in typical banking operations. In this regard, the RM is valued in premium banking not as a premium product and transaction consultant but as a trusted financial advisor.

Hypothesis 4 (H4): Quick and smooth onboarding supported by a well-designed welcome pack in premium banking positively influences the premium digital customer experience.

A positive premium customer experience includes an emerging perception of becoming a premium customer at the onboarding stage. Supposing that the level of service, including both human and digital touch, is well established, then all the technical onboarding procedures require minimum effort and time from the customer. If the bank's products and their materials' visual characteristics correspond to a high-quality standard, then the premium digital customer acquires a targeted understanding of the value of the premium banking service. 


\section{Methodology}

The research data are obtained through a survey carried out in cooperation with Russian research company, Frank RG, among the 13 largest retail banks in Russia that propose separately designed premium banking packages (Frank 2020). The authors' research study design is shown in Figure 1.

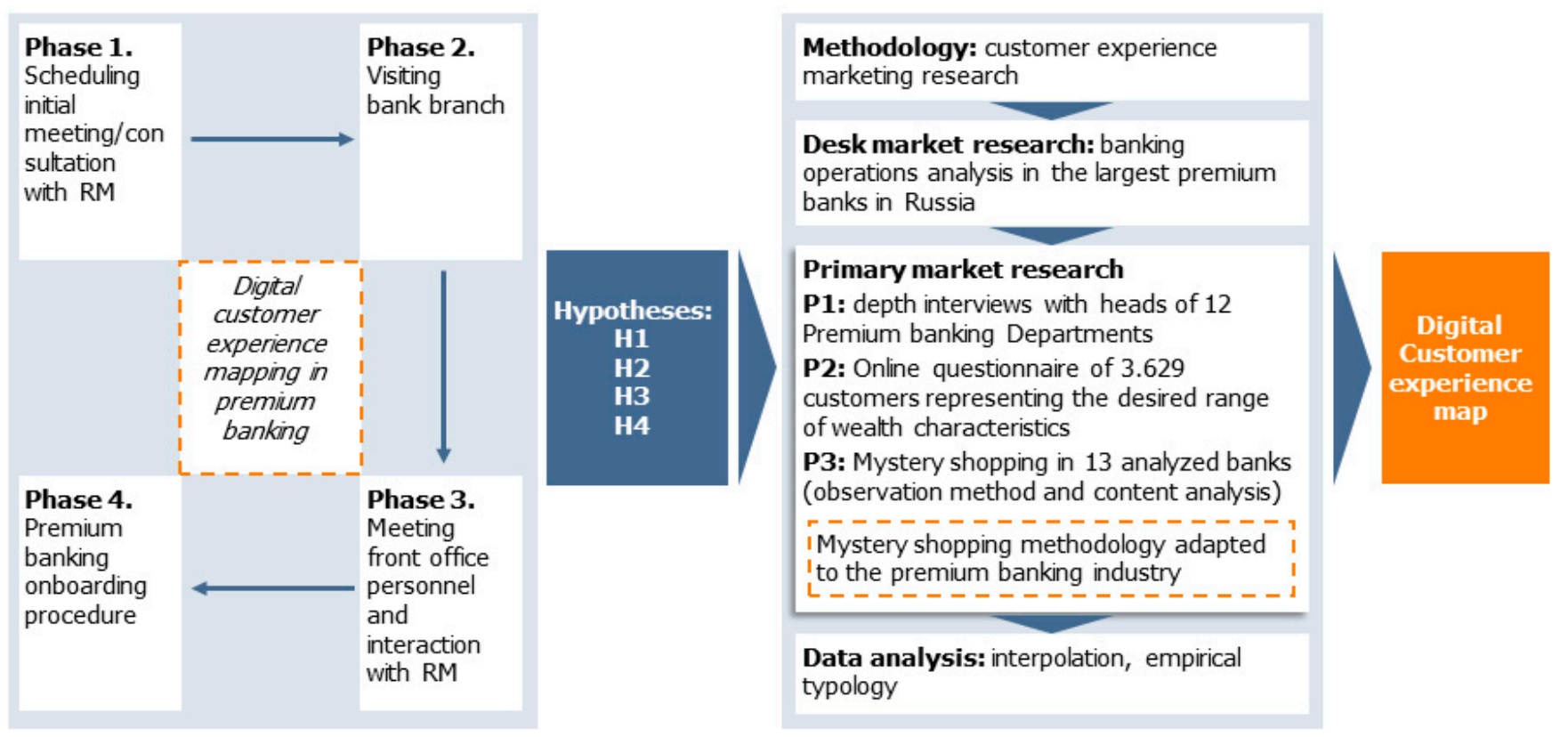

Figure 1. Research concept model of the customer experience study in Russia's premium banking (authors' findings).

A similar study was conducted by Frank RG and the research team in 2019 allowing for a comparison of dynamics (Frank 2020).

The Mystery Shopping method serves as the basis for the comprehensive marketing research of customer experience. For this reason, we improved the methodology of planning and conducting covert participant observation (Saha 2009; Pinar et al. 2010; Furnival et al. 2012; Tarantola et al. 2012; Su and Tsai 2014; Amudha et al. 2018; Jacob et al. 2018; and Manivannan and Sarah JP 2018), as well as adapting it to the premium banking industry. For this research, the Mystery Shopping methodology included 12 successive concrete stages presented in Table 1.

Table 1. Mystery shopping methodology of customer experience analysis in premium banking (authors' findings).

\begin{tabular}{cr}
\hline No. Stages & Description of Research Stages \\
\hline $1 . \quad \begin{array}{c}\text { Defining goals and objectives of } \\
\text { the research }\end{array}$ & $\begin{array}{c}\text { Identifying priority opportunities and threats (barriers) that } \\
\text { facilitate/prevent digital customers of premium banking from } \\
\text { receiving a positive experience/ perception of experience at the } \\
\text { key stages of interaction with a bank in the era of extensive } \\
\text { digitalization in banking, enabling improved decision-making } \\
\text { processes in banking marketing management. }\end{array}$ \\
\hline 2. & $\begin{array}{c}\text { Desk market research: general overview of challenges and } \\
\text { opportunities that lead to customer experience improvement, } \\
\text { product and service characteristics, and principles of banking } \\
\text { operations in Russia's largest premium banks. }\end{array}$ \\
& $\begin{array}{c}\text { Field market research: covert participant observation that } \\
\text { presents customer experience evaluations provided by Mystery } \\
\text { Shoppers following the main customer interaction scenarios in } \\
\text { premium banking. }\end{array}$ \\
\hline
\end{tabular}


Table 1. Cont

\begin{tabular}{|c|c|c|}
\hline No. & Stages & Description of Research Stages \\
\hline 3. & Sampling procedure & $\begin{array}{l}\text { Sampling method: non-probability sampling; } \\
\text { Sample size: the } 13 \text { largest retail banks in Russia that propose } \\
\text { separately designed premium banking programs; } \\
\text { Sample geography: Moscow and St. Petersburg (Russia). }\end{array}$ \\
\hline 4. & $\begin{array}{l}\text { Defining portraits for } \\
\text { Mystery Shoppers }\end{array}$ & $\begin{array}{l}\text { Mystery Shopper portraits conform to three premium banking } \\
\text { customer portraits: } \\
\text { "Saver": predominantly accumulates funds, below } \\
\text { average spendings; } \\
\text { "Spender": predominantly spends, below average savings; } \\
\text { "Saver \& spender": savings and spendings on average levels } \\
\text { and above. }\end{array}$ \\
\hline
\end{tabular}

Mystery Shoppers' scripts, recruitment, and guidance of Mystery Shoppers

6.

Developing a plan of Mystery Shoppers' interaction with banks
The scripts for Mystery Shoppers corresponds to: Goals and objectives of the research; Mystery shopper portraits;

Main characteristics of premium banking products and services revealed through desk market research.

Mystery Shoppers provide measuring of premium banking customer experience following the main customer scenarios:

Phase 1. Scheduling an initial meeting/consultation with the RM;

Phase 2. Visiting the bank branch;

Phase 3. Meeting with the RM;

Phase 4. Premium banking onboarding.
Mystery shopping study schedule: June-September 2020;

Prediction and prevention of the potential risk of a Mystery

Shopper being disclosed: individual training programs, testing the scripts, practicing necessary techniques and reactions; Study limitations: Mystery Shoppers' subjectivity in evaluation processes, reliance on personal preferences, previous banking experience, "comparison effect".

Every Mystery Shopper opens several premium banking packages in different banks within the sample and following the onboarding procedure in 13 banks: 2-3 opened premium banking packages ( 2 packages opened in branches, additional package opened remotely if available, cumulatively-32 packages)

The initial meetings/consultations with the RM are arranged

for Mystery Shoppers following various scenarios:

Meeting/ consultation in the branches: arrangements in advance through banks' contact centers, or by submitting online application forms;

Remote (telephone) consultation;

In-person meeting/consultation outside the branches at the Mystery Shopper's home.

Audio recording transcription and analysis of initial Mystery Shopping visits; adjusting the scripts and actions of the Mystery Shoppers if necessary. 
Table 1. Cont.

\begin{tabular}{|c|c|c|}
\hline No. & Stages & Description of Research Stages \\
\hline 11. & $\begin{array}{l}\text { Data processing and analysis. } \\
\text { Evaluation system }\end{array}$ & $\begin{array}{c}\text { Mystery Shoppers evaluated every bank in the sample by the } \\
\text { list of parameters logically grouped corresponding to the } \\
\text { selected customer scenario phases: } \\
\text { Phase 1: Scheduling an initial meeting/consultation with the } \\
\text { RM: } 6 \text { groups, } 45 \text { parameters in total; } \\
\text { Phase 2: Visiting the bank branch: } 3 \text { groups, } 14 \text { parameters } \\
\text { in total; } \\
\text { Phase 3: Meeting with the RM: } 7 \text { groups, } 25 \text { parameters in total; } \\
\text { Phase 4: Premium banking onboarding: } 7 \text { groups, } \\
\quad 33 \text { parameters in total. } \\
\text { Every parameter is evaluated by Mystery Shoppers on a scale } \\
\text { from 0\% to } 100 \% \text { (five evaluation marks: } 0 \%, 25 \%, 50 \%, 75 \% \text {, } \\
\text { 100\%). Banks receive scores from three different Mystery } \\
\text { Shoppers. The total scores are grouped, aggregated, and } \\
\text { divided into resulting performance categories: Category } 1: \\
\text { 100\%, Category 2: } 99-80 \%, \text { Category 3: } 79-60 \% \text {, Category } 4: \\
\text { 59-41\%, Category 5: below } 40 \% \text {. These categories are } \\
\text { considered as final indicators of service quality and delivered } \\
\text { customer experience. }\end{array}$ \\
\hline 12. & $\begin{array}{c}\text { Creating a Premium Digital Customer } \\
\text { Experience Map to develop } \\
\text { recommendations }\end{array}$ & $\begin{array}{l}\text { Identifying barriers and opportunities for applying a } \\
\text { customer-centricity business model in premium banking and } \\
\text { providing insights into ways of digital premium customer } \\
\text { experience improvement. } \\
\text { Creating a Premium Digital Customer Experience Map and } \\
\text { providing performance comparison for two banks as } \\
\text { an example. }\end{array}$ \\
\hline
\end{tabular}

The portraits for Mystery Shoppers described in the Mystery Shopping methodology (Stage 4) were created based on guidelines traditionally followed in the marketing research field (Frank 2020; and Phan et al. 2019). Three distinct premium banking customer portraits-saver, spender, and saver-spender-emerged within our research findings based on interviews with experts and customer questionnaires. The portraits are differentiated by customers' attitudes toward capital saving and spending. Additionally, portraits were differentiated by socio-demographic, psychographic, and behavioral characteristics (Frank 2020) (Table 2).

Table 2. Mystery Shopper portraits (Author's findings).

\begin{tabular}{|c|c|c|c|c|c|c|}
\hline $\begin{array}{l}\text { Parameters of } \\
\text { Mystery } \\
\text { Shopper } \\
\text { Portrait }\end{array}$ & \multicolumn{2}{|c|}{$\begin{array}{c}\text { "Saver" } \\
\text { Predominantly Accumulates } \\
\text { Funds, below Average Spendings }\end{array}$} & \multicolumn{2}{|c|}{$\begin{array}{l}\text { "Spender" } \\
\text { Predominantly Spends, } \\
\text { below Average Savings }\end{array}$} & \multicolumn{2}{|c|}{$\begin{array}{l}\text { "Saver \& Spender" } \\
\text { Saving and Spendings on } \\
\text { Average Levels and Above }\end{array}$} \\
\hline \multicolumn{7}{|c|}{ Socio-demographic characteristics } \\
\hline Age & 34 years & 40 years & 25 years & 40 years & 27 years & 45 years \\
\hline Gender & Female & Female & Male & Female & Male & Female \\
\hline Family status & $\begin{array}{c}\text { Single, } \\
\text { no children }\end{array}$ & $\begin{array}{l}\text { Divorced, } \\
\text { two children }\end{array}$ & $\begin{array}{c}\text { Single, } \\
\text { no children }\end{array}$ & $\begin{array}{l}\text { Divorced, } \\
\text { one child }\end{array}$ & $\begin{array}{c}\text { Single, } \\
\text { no children }\end{array}$ & $\begin{array}{c}\text { Married, } \\
\text { three children }\end{array}$ \\
\hline Bankable assets & RUB $4 \mathrm{mln}$ & RUB 6 mln & RUB $1.5 \mathrm{mln}$ & No & RUB $1.5 \mathrm{mln}$ & RUB 8 mln \\
\hline $\begin{array}{l}\text { Monthly } \\
\text { spendings }\end{array}$ & $\begin{array}{c}\text { below } \\
\text { RUB 150,000 }\end{array}$ & $\begin{array}{c}\text { below } \\
\text { RUB 150,000 }\end{array}$ & $\begin{array}{c}\text { above } \\
\text { RUB 250,000 }\end{array}$ & $\begin{array}{c}\text { above } \\
\text { RUB 400,000 }\end{array}$ & $\begin{array}{c}\text { above } \\
\text { RUB 400,000 }\end{array}$ & $\begin{array}{c}\text { above } \\
\text { RUB 250,000 }\end{array}$ \\
\hline \multicolumn{7}{|c|}{ Psychographic characteristics } \\
\hline Psychotype & Rational & otional & Impulsix & motional & Rationa & agmatic \\
\hline
\end{tabular}


Table 2. Cont.

\begin{tabular}{|c|c|c|c|}
\hline $\begin{array}{l}\text { Parameters of } \\
\text { Mystery } \\
\text { Shopper } \\
\text { Portrait }\end{array}$ & $\begin{array}{c}\text { "Saver" } \\
\text { Predominantly Accumulates } \\
\text { Funds, below Average Spendings }\end{array}$ & $\begin{array}{l}\text { "Spender" } \\
\text { Predominantly Spends, } \\
\text { below Average Savings }\end{array}$ & $\begin{array}{l}\text { "Saver \& Spender" } \\
\text { Saving and Spendings on } \\
\text { Average Levels and Above }\end{array}$ \\
\hline \multicolumn{4}{|c|}{ Behavioral characteristics } \\
\hline $\begin{array}{l}\text { Basic gain/ } \\
\text { values }\end{array}$ & Asset allocation, investments & Premium lifestyle & Financial gains \\
\hline $\begin{array}{l}\text { Selection } \\
\text { criteria }\end{array}$ & $\begin{array}{c}\text { Bank reliability } \\
\text { Relation Manager as a trusted } \\
\text { advisor } \\
\text { Service } \\
\text { Investment opportunities }\end{array}$ & $\begin{array}{c}\text { Additional privileges } \\
\text { Service } \\
\text { Positive emotions } \\
\text { Demonstrative behavior } \\
\text { (privileged banking service, black } \\
\text { card, etc.) }\end{array}$ & $\begin{array}{l}\text { Bank reliability } \\
\text { Cards bonus programs maximum } \\
\text { gains } \\
\text { Lower costs for banking services } \\
\text { Investment opportunities }\end{array}$ \\
\hline $\begin{array}{l}\text { Eligibility } \\
\text { criteria for } \\
\text { premium } \\
\text { banking }\end{array}$ & $\begin{array}{l}\text { Meets requirements: } \\
\text { monthly balances }\end{array}$ & $\begin{array}{l}\text { Meets requirements: } \\
\text { monthly card transactions } \\
\text { If requirements are not met: } \\
\text { monthly commission }\end{array}$ & $\begin{array}{l}\text { Meets requirements: } \\
\text { monthly balances } \\
\text { or/and card transactions }\end{array}$ \\
\hline
\end{tabular}

Mystery Shopper portraits conform to three premium banking customer portraits. With the assistance of Frank RG, we recruited six Mystery Shoppers-two recruits per each Mystery Shopper portrait (Frank 2020). For the current research, the resulting evaluation scores of banks completed by Mystery Shoppers of different portraits were aggregated, enabling the presentation of a comprehensive premium digital customer experience within the four research phases.

\section{Research Results}

Data analysis highlights a distinct shift towards digitalization in customer interaction practices in premium banking and customers' behavior and preferences. The results of customer questionnaires and expert interviews revealed that the premium banking customer segment shows the highest engagement with digital channels: desktop online banking platforms and mobile banking applications (Frank 2020) (Figure 2).

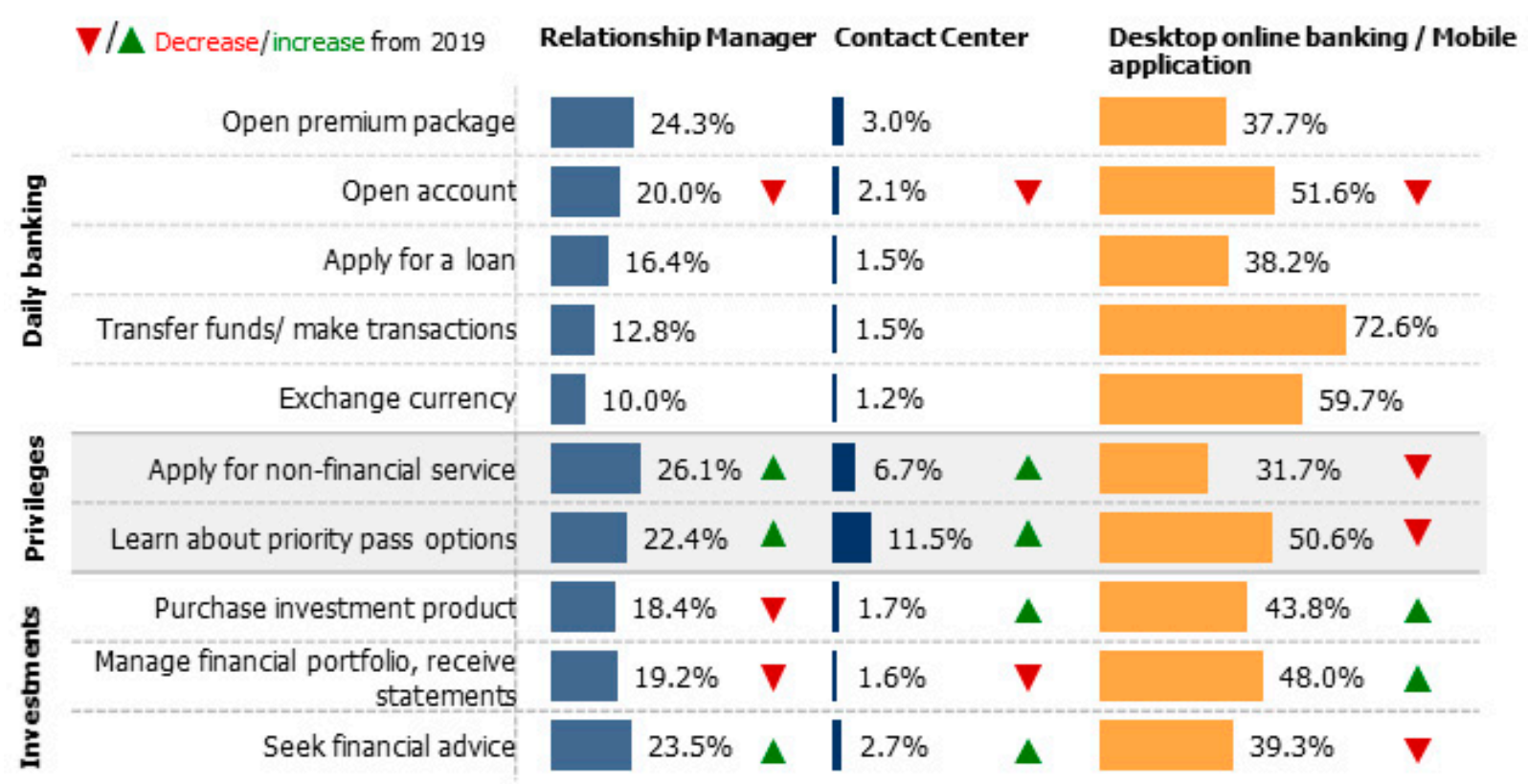

Figure 2. Channels that digital premium customers prefer (Frank 2020) (authors' findings). 
The COVID-19 pandemic has stimulated the banks to significantly accelerate their digitalization programs to ensure that customers could access services online. A customer questionnaire in 2020 revealed the increasing willingness of digital premium customers to solve through online services even more complicated issues such as investments. However, digital premium banking customers still value human engagement with their RMs when they need professional advice or solutions to more complex issues that cannot be resolved digitally. Importantly digital premium customers normally do not prefer human interactions with other bank personnel besides their RM. For this reason, the covert participant observation research-Mystery Shopping-focuses on a digital premium customer's digital and human interaction with premium banks, measuring the level of service and premium digital customer experience.

According to the Mystery Shopping methodology (Table 1), the current study scrutinizes the four main phases of a digital premium customer's interactions with a premium bank: Phase 1-scheduling an initial meeting/consultation with the RM; Phase 2-visiting the bank branch (except for one bank in the analyzed sample that operates digitally); Phase 3-meeting front office personnel and interaction with the RM; Phase 4-premium banking onboarding procedure and the following customer experience. The research results are presented in a logical order of the interaction phases mentioned above (Frank 2020).

Phase 1. Scheduling an Initial Meeting/Consultation with RM: Customer Experience Evaluation

Mystery Shoppers positively evaluated their customer experiences on the banks' websites (both desktop and mobile versions) in almost all banks (Table 3). The evaluation scale of quality included two dimensions: the processing speed and convenience while searching for information about premium banking; and searching for necessary phone numbers, application forms, and chats. Compared to the previous survey conducted in 2019, many banks launched chat rooms for virtual communication with customers. Still, none of the analyzed banks proposed dedicated chat rooms for premium banking customers. In three banks, digital premium customers were offered communication options with the bank through messenger services, enabling them to receive prompt notifications (e.g., regarding meeting details or any other issues). Only one bank accommodated both website chat rooms and messenger options delivering the highest level of convenience in communications.

Table 3. Scheduling an initial meeting/consultation: premium digital customer experience evaluation (authors' findings).

\begin{tabular}{|c|c|c|c|c|c|}
\hline \multirow{3}{*}{$\begin{array}{c}\text { Customer Experience: A Group of Parameters } \\
\text { for Evaluation } \\
\text { (6 Groups, } 45 \text { Parameters in Total) }\end{array}$} & \multicolumn{5}{|c|}{ Performance Categories Based on Mystery Shoppers' Evaluations } \\
\hline & 1 & 2 & 3 & 4 & 5 \\
\hline & \multicolumn{5}{|c|}{ Number of Banks in the Performance Category } \\
\hline 1. Information search: website mobile version (10 par.) & 1 & 10 & 1 & - & 1 \\
\hline 2. Information search: website desktop version (10 par.) & - & 12 & - & 1 & - \\
\hline $\begin{array}{l}\text { 3. Communication through bank's chat-if available } \\
\text { (8 par.) }\end{array}$ & - & - & 3 & 3 & 1 \\
\hline 4. Application form on the website-if available ( 7 par.) & - & 3 & 7 & 1 & - \\
\hline $\begin{array}{l}\text { 5. Communication through bank's contact center-if } \\
\text { available ( } 6 \text { par.) }\end{array}$ & 1 & 2 & 5 & 3 & 1 \\
\hline 6. Meeting confirmation by the manager (4 par.) & 1 & 2 & 3 & 3 & 3 \\
\hline
\end{tabular}

When scheduling an initial meeting with the RM, positive customer experience included communication with specialists from the intense premium contact center who made the necessary appointments and transferred information to the RMs of the selected branch for additional confirmation contacts. Mystery Shoppers considered the possibility of being transferred directly to the Relationship Manager a benefit during the initial call to the contact center. When scheduling the meeting through an application form on the website, 
a direct callback from an RM was also perceived as an extremely positive customer experience. It eliminated any extra communications with call center representatives, who often provide dissatisfactory servicing (lack of professionalism, annoying scripts, misleading information, etc.). Compared to the 2019 survey, customers did not identify problems or failures when submitting the form; the conversion increased: $78 \%$ of customers received an accurate confirmation of a meeting from the manager (Figure 3).

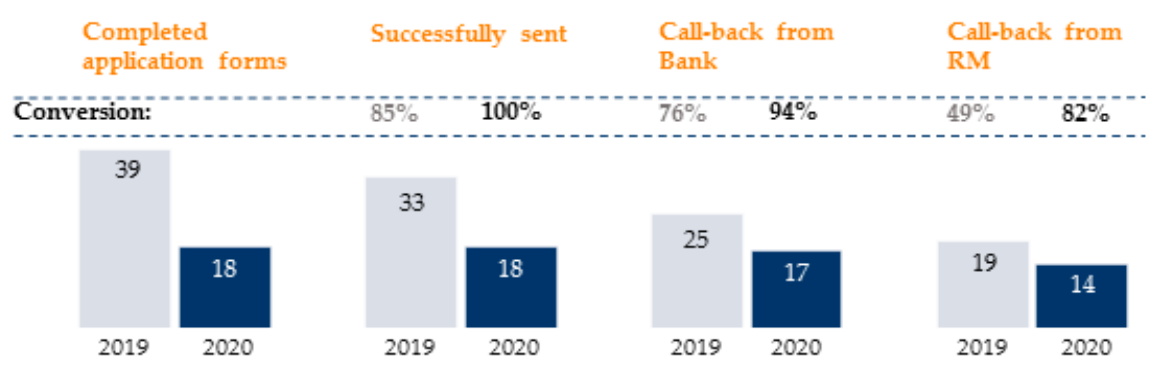

Figure 3. Scheduling an initial meeting/consultation via the application form: conversion level (authors' findings).

Contact centers of some banks were responsible only for transferring information to the RMs and did not make appointments. Such practice extended and complicated the customer journey and increased the risk of customer loss if a manager failed to contact. A confirmation callback from RMs was regarded to be an important part of customer experience. Mystery Shoppers evaluated the waiting period, the convenience of communication (direct call/SMS/WhatsApp), and the provision of RMs' contact details, which was crucial if a customer needed to reschedule a meeting.

Only one bank demonstrated an ability to organize high-quality communications with contact center employees and RMs (Category 1 in Table 3). Contact center representatives were delicate, clarified customers' needs, provided accurate information complying with the customers' requests, and helped choose a convenient branch, fixed date, and time for a meeting. Afterward, the RMs contacted the customers promptly and confirmed all the necessary details politely and comfortably.

The negative customer experience within Phase 1-scheduling an initial meeting/ consultation-included:

- Difficulties with finding a phone number of the premium contact center (six banks);

- Lack of confirmation of the scheduled meetings with RMs (no confirmation in 39\% cases);

- Failure to schedule a meeting for a certain time (one bank);

- Failure to schedule a meeting through the phone number of a contact center presented on the website- this required additional calls to premium contact centers (seven banks);

- Excessive contacts and additional time burdens (one bank);

- Annoying scripts in contact centers, lack of focus on customers' needs (nine banks).

The negative customer experience of Mystery Shoppers detected barriers that complicated the selection process and further interaction with a premium bank within a highly competitive market.

Phase 2. Visiting the Branch: Customer Experience (Perceptions) Evaluation

Mystery Shoppers distinguished comfortable interaction in branches before the meeting with RM in most analyzed banks (Table 4). At the branch entrance, a bank employee greets customers, clarifies the purpose of the visit, helps with the appointment terminal (if necessary), escorts the customer to a dedicated premium service area, and offers tea or coffee in the priority lounge. The waiting time for an RM was below 5-7 min in most banks. 
Table 4. Visiting the branch: premium digital customer experience evaluation (authors' findings).

\begin{tabular}{|c|c|c|c|c|c|}
\hline \multirow{3}{*}{$\begin{array}{l}\text { Customer Experience: A Group of Parameters for } \\
\text { Evaluation } \\
\text { (3 Groups, } 12 \text { Parameters in Total) }\end{array}$} & \multicolumn{5}{|c|}{ Performance Categories Based on Mystery Shoppers' Evaluations } \\
\hline & 1 & 2 & 3 & 4 & 5 \\
\hline & \multicolumn{5}{|c|}{ Number of Banks in the Performance Category * } \\
\hline 1. Branch experience before the meeting with $\mathrm{RM}$ ( 6 par.) & 1 & 7 & 3 & 1 & - \\
\hline 2. Level of comfort in a premium service area (6 par.) & - & 3 & 7 & 2 & - \\
\hline \multirow{8}{*}{ 3. Network of branches with premium areas (2 par.) } & \multicolumn{5}{|c|}{$\begin{array}{l}\text { Share of branches with premium areas within the whole network in } \\
\text { Moscow, } \%\end{array}$} \\
\hline & 100 & $99-80$ & $79-60$ & $59-41$ & Below 40 \\
\hline & \multicolumn{5}{|c|}{ Number of banks in the performance category } \\
\hline & 1 & 4 & 3 & 4 & - \\
\hline & \multicolumn{5}{|c|}{$\begin{array}{l}\text { Share of branches with premium areas within the whole network in } \\
\text { other Russian regions, } \%\end{array}$} \\
\hline & 100 & $99-80$ & $79-60$ & $59-41$ & Below 40 \\
\hline & \multicolumn{5}{|c|}{ Number of banks in the performance category } \\
\hline & 1 & - & 3 & 1 & 7 \\
\hline
\end{tabular}

Notes: The scores received from Mystery Shoppers are transformed into cumulative scores for each group of parameters per bank. Category 1: $100 \%$, Category 2: $99-80 \%$, Category 3: 79-60\%, Category 4: 59-41\%, Category 5: below $40 \%$. ${ }^{*} 12$ banks are included in the analyzed sample within Phase 2 as one bank operates digitally without branches; if necessary, RMs hold meetings at any place convenient for customers.

The cumulative score of the second group of parameters-“Level of comfort in a premium service area"-includes Mystery Shoppers' subjective measures of comfort: premises design, the state of furniture and equipment, and privacy level during the meeting (soundproofing, closed doors, etc.) (Figure 4).

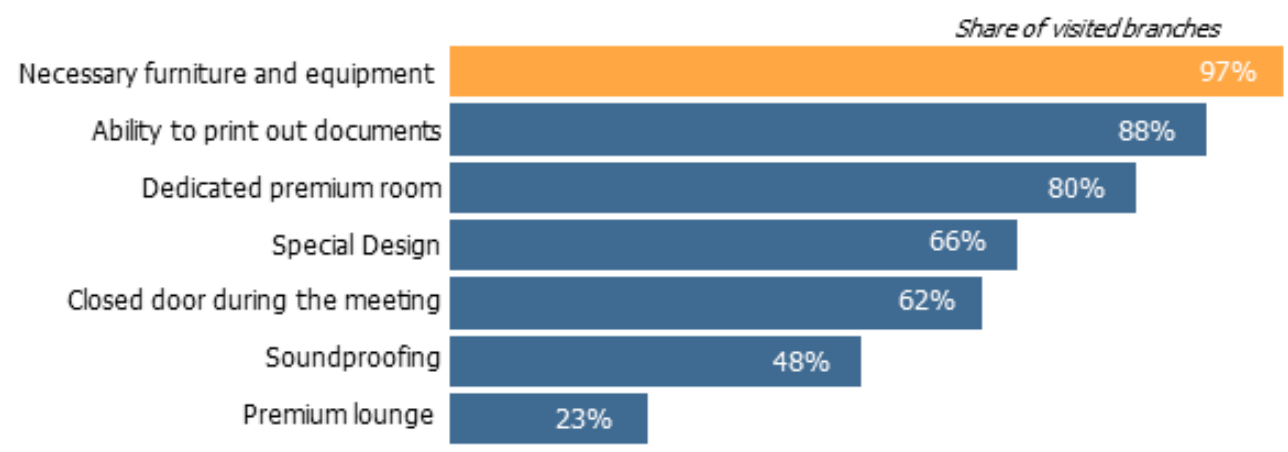

Figure 4. Valuable characteristics of the premium area in the analyzed banks (authrs' findings).

A premium service area includes a dedicated room- the RM's office (minimum service standard) or a dedicated zone with several rooms. Normally the premium area is physically separated from retail banking space, offers a premium lounge, and avoids any intersection with mass retail banking clientele.

The negative customer experience within Phase 2 (visiting the branch) included the following cases:

- Consultation in the retail banking area-the lack of premium comfort;

- Absence of a premium lounge-the inconvenience of waiting in a common retail banking area;

- Overcrowding in branches-the lack of premium comfort, inability to maintain social distancing during the pandemic; 
- Low privacy standards-a half-closed door in RM's office during the meeting and ambient noises (from common areas or neighboring meeting rooms, sounds of renovation, etc.).

\section{Phase 3. Meeting with RM: Customer Experience (Perceptions) Evaluation}

For the study based on the conducted questionnaire and expert interviews, we identified two groups of RM skills - professional (hard skills) and communication (soft skills) that contained seven main competencies of RMs that are important for digital premium customers (Frank 2020) (Table 5). Professional skills included three competencies: detailed knowledge of privileged banking services included in the premium package, relevant investment products, and lifestyle privileges. Communication skills contained four competencies: speech delivery; comfortable communication; a focus on customer's needs, gains and values. The evaluation scores of RMs provided by Mystery Shoppers were structured according to the highlighted competencies, which reduced the Mystery Shoppers' subjectivity.

Table 5. Competencies of RMs as valued by premium customers (authors' findings).

\section{Competencies}

\section{Description of the RM with the Highest Level of Competence \\ (Category 1 in the Evaluation System)}

\subsection{Level of knowledge about privileged banking services}

1.2. Level of knowledge about investment products

1.3. Level of knowledge about lifestyle privileges within the package
Provides complete, reliable information about privilege banking services within the premium package; does not mislead customers; and is well-informed about competitors' offerings and able to compare them.

Provides complete, reliable information about investment products: a broad set of features, risks and returns, fees, liquidity, asset allocation principles, taxes; and can explain the interaction process between bank and customer while investing.

Provides complete, reliable information about lifestyle privileges within the premium package; is well-informed about conditions or restrictions of the privileges; and can provide examples and assess the real value.

2.1. Speech delivery: proper language skills, clear and well-structured conversation

Communicates professionally but does not overload customers with specialist banking or English-language terminology; and presents information logically and clearly.

Communicates comfortably without obvious scripts, can build communication rapport: asks the "right" questions, actively listens, shows interest in a customer, summarizes information, and supports subsequent electronic communication.

2.2. Comfortable communication: no script, informal contact, follow-ups

Avoids pushing, focuses on the information provided by 2.3. Focus on customer's needs, gains, and values customers instead of the bank's products and services; shows an understanding of customer's needs, gains, and values; and can make customers feel that their best interests are a priority.

Manages to demonstrate all the benefits of the premium

2.4. Persuasion: ability to convince customers to become a premium client package for a certain customer; after the meeting, customers are not tired and overloaded by information, but cheered up and eager to become a premium client in the bank.

According to the Mystery Shoppers' evaluation scores, RMs in most banks in the analyzed sample demonstrated an average level of competencies (Category 3 ) in both professional and communication skills categories. A high level of communicational skills (Category 2) was revealed in five banks, whereas a high level of professional skills was found in only two banks (Table 6). None of the analyzed banks managed to score the highest level of competency in professional and communication groups. 
Table 6. Meeting with the RM: premium digital customer experience evaluation (authors' findings).

\begin{tabular}{|c|c|c|c|c|c|}
\hline \multirow{3}{*}{$\begin{array}{c}\text { Customer Experience: A Group of Parameters } \\
\text { for Evaluation } \\
\text { Competences of RM } \\
\text { (7 Groups, } 25 \text { Parameters in Total) }\end{array}$} & \multicolumn{5}{|c|}{ Performance Categories Based on Mystery Shoppers' Evaluations } \\
\hline & 1 & 2 & 3 & 4 & 5 \\
\hline & \multicolumn{5}{|c|}{ Number of Banks in the Performance Category } \\
\hline 1. Professional skills (hard skills): level of knowledge: & - & 2 & 8 & 3 & - \\
\hline 1.1. Privilege banking services (5 par.) & 3 & 7 & 3 & - & - \\
\hline 1.2. Investment products (6 par.) & 1 & 3 & 1 & 5 & 3 \\
\hline 1.3. Lifestyle privileges within the package ( 2 par.) & 1 & 1 & 2 & 6 & 3 \\
\hline 2. Communication skills (soft skills) & - & 5 & 6 & - & 2 \\
\hline 2.1. Speech delivery (3 par.) & 2 & 5 & 3 & 2 & 1 \\
\hline 2.2. Comfortable communication (3 par.) & 3 & 3 & 3 & 3 & 1 \\
\hline 2.3. Focus on customer's needs, gains, and values (3 par.) & 2 & 5 & 2 & 1 & 3 \\
\hline 2.4. Persuasion (3 par.) & 1 & 7 & 2 & 2 & 1 \\
\hline
\end{tabular}

Notes: The scores received from Mystery Shoppers are transformed into cumulative scores for each group of parameters per bank. Category 1: $100 \%$, Category 2: 99-80\%, Category 3: 79-60\%, Category 4: 59-41\%, Category 5: below $40 \%$.

RMs in most of the analyzed banks demonstrated a high level of competency in banking services (Category 1 and 2); knowledge about money transfer fees, currency exchange rates, deposit rates, cards bonus programs, etc. However, the digitalization of banking services decreased the relevance of this competence, as digital premium customers prefer self-service through digital channels in answer to such questions. However, it remains important for banks to improve or maintain a high level of this competency since disinformation of customers may lead to financial losses and, accordingly, a highly negative customer experience.

According to Mystery Shoppers' scores, the investment competence of RMs generally remained at a lower level than banking competence. Only one bank (scored Category 1 level) provided highly professional investment advice from the RM, including risk-profiling procedures and tailored investment recommendations. Half of the RMs demonstrated poor knowledge of investment products and provided no information about the new procedure of investment advice enshrined in the new Legislation Act.

In 10 banks, RMs organized additional meetings with professional investment advisors. Investment advisors presented model portfolio allocations in eight banks, but only three of them used risk-profiling tools. For the Mystery Shoppers left satisfied with the proposed portfolio diversification in five banks, in four of these, Mystery Shoppers recognized the value of an additional meeting with investment advisors. Mystery Shoppers noted that a relevant shift in investment advisory procedure might include growing the investment competence of RMs, which would enable them to serve customers in a "single window" concept without the additional engagement of investment advisors.

Mystery Shoppers pointed out a customer-friendly approach to present lifestyle privileges in one bank (scored Category 1 level): the manager used visualization, explained the principles of using privileges, provided descriptions of successful cases from real experience (personal or from other customers), managed to persuade the customer that premium banking is more than just a banking service. Most analyzed banks lacked a proper presentation of lifestyle privileges (nine banks scored Category 4 and 5 levels). Mystery Shoppers considered boring recitation of additional privileges or given examples incompatible with real-life situations as a negative customer experience. Mystery Shoppers highlighted that none of the RMs in the 13 analyzed banks presented concrete financial gains from lifestyle privileges within the packages that would provide a better understanding of the premium package value.

With regard to communication skills, RMs in the majority of analyzed banks presented relatively high results (evaluation scores with Categories 1 and 3 in 11 banks); communi- 
cated in a professional and easily comprehensible manner; focused on customer's needs, gains, and values without obvious pushing (seven banks with scores within Categories 1 and 2); provided a comfortable communication atmosphere (six banks with scores within Categories 1 and 2); and managed to persuade Mystery Shoppers to become a premium customer with a particular bank (eight banks with scores within Categories 1 and 2).

The negative customer experience within Phase 3 ("Meeting with the RM") included the following cases:

- Misleading information; a lack of trust toward the RM and the bank in general $(22 \%$ of cases);

- Low level of RMs' investment competencies. Digital premium customers need professional investment advice in case they are not professional investors; digital self-service in investments for a beginner is normally not preferred;

- Boring recitation of additional privileges or lack of real-life examples and descriptions of concrete financial gains ( $68 \%$ of cases);

- Inappropriate slang, mistakes in English-language terms, incomplete thoughts and sentences ( $20 \%$ of cases);

- Obvious scripts, formalistic conversation, lack of self-presentation and communication rapport (35\% of cases);

- Product push, lack of focus on the customer's needs (33\% of cases);

- Heavy workloads: RMs were distracted from the meeting, losing track of the conversation, and showing a limited interest in potential customers ( $9 \%$ of cases).

Phase 4. Premium Banking Onboarding: Customer Experience (Perceptions) Evaluation

The results of Mystery Shopping revealed weaknesses of the customer experience in the premium onboarding process (Table 7). In the majority of cases, Mystery Shoppers opened premium packages in branches (10 banks). Positive premium digital customer experience included the opportunity of opening packages remotely - via a contact center (5 banks) or application form on the website (six banks).

Table 7. Onboarding: premium digital customer experience evaluation (authors' findings).

\begin{tabular}{|c|c|c|c|c|c|}
\hline \multirow{3}{*}{$\begin{array}{c}\text { Customer Experience: A Group of Parameters } \\
\text { for Evaluation } \\
\text { (7 Groups, } 33 \text { Parameters in Total) }\end{array}$} & \multicolumn{5}{|c|}{ Performance Categories Based on Mystery Shoppers' Evaluations } \\
\hline & 1 & 2 & 3 & 4 & 5 \\
\hline & \multicolumn{5}{|c|}{ Number of Banks in the Performance Category } \\
\hline 1. Premium package opening in a branch ${ }^{* *}$ (4 par.) & 1 & - & 7 & 1 & 1 \\
\hline $\begin{array}{l}\text { 2. Remote premium package opening via contact } \\
\text { center-if available ( } 6 \text { par.) }\end{array}$ & - & 2 & 2 & 1 & - \\
\hline $\begin{array}{l}\text { 3. Remote premium package opening via the application } \\
\text { form on the website- - if available ( } 6 \text { par.) }\end{array}$ & - & 1 & 4 & 1 & - \\
\hline 4. Notification of card issue ( 3 par.) & 2 & 2 & 3 & 4 & 1 \\
\hline 5. Premium package delivery in a branch (5 par.) & 2 & 1 & 8 & - & 1 \\
\hline 6. Premium package delivery-remote opening (5 par.) & 1 & 1 & 1 & 2 & 1 \\
\hline $\begin{array}{l}\text { 7. Subjective perception of being a premium customer } \\
\text { (4 par.) }\end{array}$ & 1 & 3 & 2 & 6 & - \\
\hline
\end{tabular}

Mystery Shoppers highlighted an exemplary case of branch onboarding procedure in only one bank. Paperwork was done by the manager quickly; during the meeting, RM opened current and saving accounts, issued cards (momentary issue), assisted with mobile application uploading, presented special characteristics of the application, and demonstrated the main customer scenarios (products information, money transfer, cards spending 
control, Apple Wallet, etc.). The negative customer experience included the lengthy opening procedure, requirements for excessive information or information previously provided, and communications with the RM on extraneous, irrelevant topics.

The premium customer experience during remote premium package opening via a contact center included the following limitations:

- Switches between various employees;

- Extra requests for information previously provided;

- Long conversations (over $15 \mathrm{~min}$ );

- Lack of a follow-up call from the RM.

The top model case for remote premium package opening via the application form on the website was presented in one bank (Category 2 score): form completion continued for less than $5 \mathrm{~min}$; and Mystery Shoppers received well-structured, graphic, and sequential information (via SMS and e-mail) about the application process, acceptance, the appointment of the meeting, and the explanation of card issue procedure. The calls from RMs followed shortly.

The negative experience of the customer when registering a premium package resulted in discomfort for the following reasons:

- It was necessary to provide redundant or previously provided information;

- Time was spent on unnecessary communication with the manager;

- No information had been received after applying for the card.

\section{Discussion}

Our research identified the priorities leading to premium digital customer experience improvement. The study confirmed Hypothesis 1 (H1): at Phase 1 (Scheduling an initial meeting/consultation with RM), the convenience of information searches on a bank's website positively influences the premium digital customer experience. Of the analyzed banks, $85 \%$ of them provided customers the highest level of service (Category 1 and 2) when searching for information on theirwebsites (both desktop and mobile versions). Additionally, $46 \%$ of the banks had no messenger services, and $12 \%$ of banks had no application forms for scheduling the initial meeting with the RM. The necessary improvements of customer experience include the following:

- The upgrading of application forms and increase in the conversion rate;

- Expanding the availability of the maximum number of options for the initial meeting schedule-applications form, chats, contact centers;

- No failures of scheduling meetings through contact centers;

- Reducing of cases when the RM is not prepared for the meeting or even absent, or another RM replaces the colleague without informing the Mystery Shopper.

Hypothesis $2(\mathrm{H} 2)$ was confirmed because only one bank offered a premium zone in every retail branch in Moscow and the surrounding regions. Only 33\% of banks offered premium zones in above $80 \%$ of branches in Moscow. In contrast, $58 \%$ of banks offered premium zones in below $40 \%$ of branches in the surrounding regions. Additionally, only $25 \%$ of the analyzed banks suggested an above-average comfort level in the premium zones (Category 2). At the same time, five banks from the analyzed sample offered dedicated premium branches available only for premium customers. Such branches were usually located in city areas most convenient for premium customers, such as areas with premium office clusters, premium-class, and luxury housing. Dedicated premium branches were of particular comfort and best suited customers' privacy requirements. They offered a single design and were close to the format of private banking. According to Mystery Shoppers' evaluations, dedicated premium branches suggested the best customer experience.

One bank within the sample had no branches and operated fully digitally. The communication with the RM was carried out via remote channels (phone calls, messengers, e-mails). Face-to-face meetings were rare and usually happened at a non-banking location convenient for customers when solving complex issues related to investment consulting. 
Mystery Shoppers judged such customer experiences both positively and negatively. The ability of the bank to establish efficient remote processing of daily banking needs was regarded as a definitive advantage. The convenience of meeting in a non-banking space might be valuable for the reason that it saves time. Nevertheless, Mystery Shoppers noted that they prefer to allow time for a meeting in a bank's branch for security reasons in complicated issues. For this reason, our recommendation for digital banks would be to have at least one high-quality premium banking branch area in a prime location.

Concerning improving the customer experience at Phase 3 (Meeting with the RM), the following should be noted. The study confirmed Hypothesis $3(\mathrm{H} 3)$ : in $77 \%$ of analyzed banks, RMs demonstrated a high level of competence in banking services (Category 1 and 2). However, rapid digitalization in banking revealed the importance of changing the role of the RM in premium banking. The premium digital customer preferred digital self-service while collecting and analyzing information, purchasing products, and performing typical transactions. For this reason, the status of the RM in premium banking should be shifted from product and transaction consultant to trusted financial advisor. The main responsibilities of the product and transaction consultant, such as providing information, paperwork, helping with basic banking transactions, can be redeployed in digital services. The trusted financial advisor, by contrast, could provide customers with a human interaction that are difficult to do digitally. The trusted financial advisor is a person with a diverse range of highly developed professional and communicational skills, able to think outside the box and solve complex, off-standard tasks making the life of a premium digital customer easier, bringing additional value and positive emotions into banking.

The Mystery Shopping results within the current research revealed that RMs in many banks lack professional and communicational competencies and could become "trusted financial advisors" for the digital premium customers.

Hypothesis 4 (H4) was confirmed by our research results, complying with the Mystery Shopping study: only one bank ( $8 \%$ ) managed to provide an understanding of premium banking value upon the accomplishment of all the necessary onboarding procedures: the opening of the premium package (accounts and cards) was quick and smooth; Mystery Shoppers noticed no errors; the difference between premium service and common retail banking was obvious; and the design of cards and welcome packs was remarkable and impressive. The digital customer experience of premium package opening via the application form on the website at Phase 4 (Premium banking onboarding) was possible to upgrade by enhancing usability through:

- Limiting typing with auto-completion, providing tooltips, using input masks, mitigating errors with inline validation, and checking address data;

- Minimizing the number of fields and withdrawing from requesting excessive information;

- Offering options for the seamless completion of the form in any convenient way (SMS message, e-mail);

- Auto-saving of the entered data if the process was interrupted, enabling the continuation of completing the form.

Based on the results presented in the above Mystery Shopping research, we have carried out a comprehensive analysis of various scenarios between a digital customer and a premium bank and created a Premium Digital Customer Experience Map which is proposed to be exploited as an effective tool for planning and improving premium banking services provided through different channels (Figure 5). 


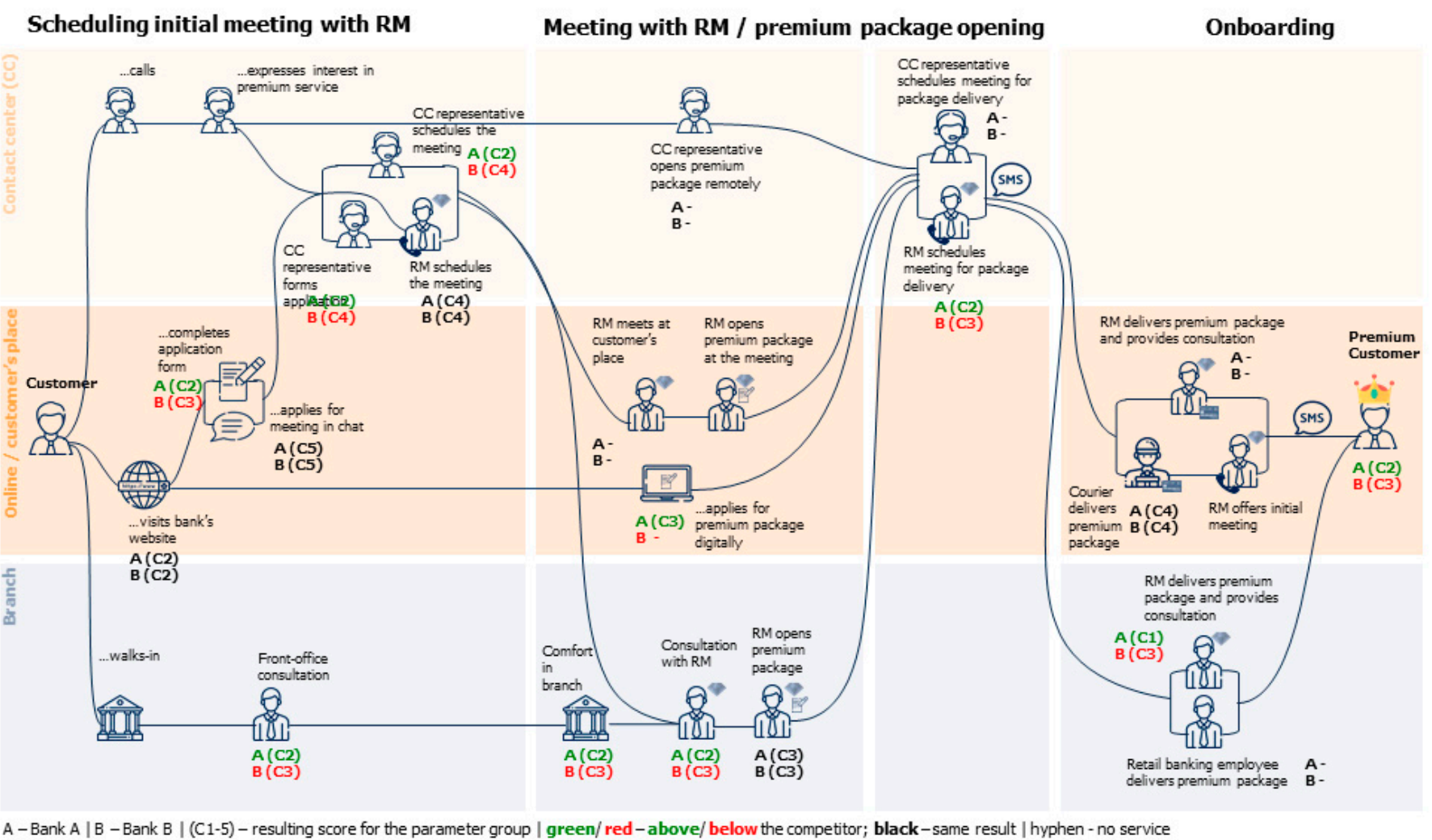

Figure 5. Premium Digital Customer Experience Map: a comparison between two competing banks (authors' findings).

Additionally, the proposed Premium Digital Customer Experience Map stands up as a tool for comparing the performance of two competing banks. Based on the research data, we have shortlisted two banks-conditionally called Bank A and Bank B-with comparable characteristics in three selected indicators: the number of premium branches, market experience in premium banking, and private ownership. The scores received in the analyzed interaction phases were visualized on the map, simplifying comparison procedures.

The created map illustrates the main phases of interaction between customers and premium banks and describes potential customer feedback following premium banking engagement. It consolidates quantitative and qualitative data and contributes to the deeper analysis of premium customer behavior and motivation at different touchpoints in a bank, strengthening the ability to optimize customer interactions with the bank and predict future customer behavior.

\section{Conclusions}

The results of this research are based on the authors' methodology for a comprehensive marketing study devoted to digital customer experience/digital customer perception of the interaction experience with premium banking in the 13 largest retail banks in Russia.

The comprehensiveness and reliability of the conducted research work was ensured through the following measures:

- An online questionnaire administered to a large-scale representative sample of 3629 customers who reflected the desired range of wealth characteristics;

- An applied qualitative research method based on in-depth interviews with heads of premium banking departments in 12 of the largest retail banks in Russia;

- The authors created a new Mystery Shopping methodology and applied it to the 13 largest Russian banks included in the study. This novel approach to the Mystery Shopping research method enabled the authors to adapt and improve the conventional methodology of analyzing customer experience within the premium banking sector in Russia; 
- Recruitment of Mystery Shoppers followed the three premium banking customer portraits-saver, spender, and saver-spender. These three portraits were aggregated, thereby enabling the presentation of a comprehensive premium digital customer experience within the four research phases.

The current study enabled the authors to identify major opportunities and threats (barriers) that facilitated/prevented premium banking digital customers from receiving positive experiences/developing perceptions of positive experiences at key stages of their interaction with a bank. Given the present era of extensive digitalization in the banking sector, this information will improve the decision-making process in marketing management.

Furthermore, this research study scrutinized the interaction of premium digital customers with premium banks through both online and offline banking channels. It thus revealed the barriers to and opportunities for improving the premium digital customer experience. Based on the digital premium customer experience analysis, this research work identified certain key premium banking vulnerabilities. These vulnerabilities prevented efficient and smooth interaction with digital premium customers during the following phases: scheduling an initial meeting/consultation with the RM, visiting the bank branch, meeting the RM, and onboarding to premium banking.

With the development of a digital relationship between a premium bank and a customer, the efficiency of the customer's decision-making process will be pivotally determined by the degree of intellectual effort made by the Relationship Manager. This effort involves the digital premium customer collecting, analyzing, using, and storing information digitally, regardless of the channel chosen (online or offline) for further transactions.

The research results highlighted the premium customers' choice for digital self-service in their daily banking practices, who were also more interested and willing to use online services to solve more complicated issues such as investments. Premium banking traditionally implies personal engagement with a Relationship Manager, which offers the valuable opportunity of resolving more complex issues with greater comfort. Intensive digitalization of services and banking processes will expand and improve the level of premium customers' digital experiences, obliging premium banks to seek new values for human services. This research proposed a shift in the RM's role from product and transaction consultant to a trusted financial advisor, which underscores the growing importance of developing a diverse range of professional and communication skills.

The Premium Digital Customer Experience Map created as a result of comprehensive marketing research is an effective tool for planning a client-centric marketing strategy and improving the managerial service quality in premium banking and the premium digital customer experience.

\subsection{Theoretical Contribution}

This study provides several theoretical contributions to the existing literature on Customer Experience Management. Firstly, its contribution lies in the originality of this research, which includes studying customer experience by analyzing key stages of interaction between a premium digital customer and a premium bank within the market of scarcely disclosed data. Additionally, the authors contributed to the research methodology proposing a new approach to the Mystery Shopping methodology in premium banking, including the recruitment of Mystery Shoppers following the three premium banking customer portraits: saver, spender, and saver-spender.

Second, this contribution was related to the theory that was utilized and extended in this study - the concept of Customer Experience Management based on the systematization of expected and received values of premium digital customers following the main customer scenarios, namely: scheduling an initial meeting/consultation with RM; visiting the branch; meeting with the RM; and the onboarding process. 


\subsection{Implications for Practice}

The findings from this study can be used to plan and control the marketing activities in premium banking aimed at Customer Experience Management. The key obstacles (barriers) identified by Mystery Shoppers that prevent effective digital customer interaction with the premium bank can be considered in the marketing decision-making process targeted at customer experience improvement. The marketing management of premium banking can be guided by the identified priority opportunities of customer experience improvement related to the most important customer values, including the extensive service digitalization, high-standard human touch in branches, the new role of the RM, and the importance of the subjective perception of being a premium customer.

The authors' systematization of premium digital customer values within four interaction phases will enable banks to apply an axiological approach to marketing solutions for managing the customer experience. This approach is extremely relevant in the modern market as it focuses on the customers' real values, thus changing the marketing concept of attracting and retaining premium digital customers.

The Premium Digital Customer Experience Map, created within the current research, stands out as a ready-made tool for planning and improving premium banking services provided through different channels. This map allows us to analyze the strengths and weaknesses of providing premium digital customer values, as well as optimize service procedures and marketing budgets. Additionally, the Premium Digital Customer Experience Map can be used as a tool for performance comparisons with competing banks, influencing the efficiency of competitive strategies.

\subsection{Limitations and Future Research}

Despite the study's significant contributions, we would like to acknowledge several limitations of the study, in addition to its significant findings.

This study is based on a comprehensive marketing study of premium bank branches in Moscow and St. Petersburg. In future studies, the geographical sample may be expanded by analyzing regional premium banking branches located in cities with a population of over one million (13 additional cities in Russia).

The Mystery Shoppers were recruited according to the selected three premium banking customer portraits, differentiated mainly by customers' attitudes toward capital saving and spending. Premium customer behavior can be more profoundly monitored within future research by allowing for the identification of other principles of segmentation and other types of customer portraits.

The current study includes an analysis of the customer's journey through the four key phases of digital customer interaction with a premium bank. In future studies, the interaction stages could be expanded, enriching the relevance and practical value of the research findings.

Author Contributions: Conceptualization, G.T. and L.P.; data curation, I.S.; formal analysis, G.T.; funding acquisition, R.S.; investigation, Y.G., and S.Z.; methodology, Y.G., and S.Z.; project administration, N.I.; resources, N.I.; software, Y.G., and S.Z.; supervision, Y.G.; validation, L.P.; visualization, L.P.; writing—original draft, G.T.; writing—review and editing, G.T., L.P., A.S. and Z.M. All authors have read and agreed to the published version of the manuscript.

Funding: This article is a part of a larger state-ordered scientific research, "Methodology development for competitiveness management in the commodity turnover field in the digital economy". Project No. FSSW-2020-0009.

Institutional Review Board Statement: Not applicable.

Informed Consent Statement: Informed consent was obtained from all subjects involved in the study.

Data Availability Statement: The data presented in this study are available on request from the corresponding authors.

Conflicts of Interest: The authors declare no conflict of interest. 


\section{References}

Alam, Md, Mustafa Raza Rabbani, Mohammad Rumzi Tausif, and Joji Abey. 2021. Banks' performance and economic growth in India: A panel cointegration analysis. Economies 9: 38. [CrossRef]

Albashrawi, Mousa, and Luvai Motiwalla. 2020. An integrative framework on mobile banking success. Information Systems Management 37: 16-32. [CrossRef]

Amudha, R., R. Nalini, R. Alamelu, K. Hemalatha, and M. Visvanaath. 2018. Impact of Social Media Network in Experiential Mystery Shopping. Paper presented at the 7th IEEE International Conference on Computation of Power, Energy, Information and Communication, Chennai, India, March 28-29; pp. 103-7.

Aoki, Kei, Efua Obeng, Aberdeen Leila Borders, and Deborah H. Lester. 2019. Can brand experience increase customer contribution: How to create effective sustainable touchpoints with customers? Journal of Global Scholars of Marketing Science 29: 51-62. [CrossRef]

Arenkov, I. A., I. V. Arakelova, and D. L. Katchalov. 2019. From traditional loyalty to customer experience management and digital models. RISK: Resources, Information, Supply, Competition 1: 116-22.

Asnawi, Nur, and Nina Dwi Setyaningsih. 2021. Islamic banking service innovation in customer co-creation: Its impact on customer trust, satisfaction, and loyalty. Journal of Southwest Jiaotong University 56: 65-82. [CrossRef]

Azad, Sid, Thomas Briot, Cristina Catania, Sebastien Lacroix, Violet Lentz, Jan Quensel, Frédéric Vandenberghe, and Christian Zahn. 2020. The Future of Private Banking in Europe: Preparing for Accelerated Change. McKinsey Insights. Available online: https:/ / www.mckinsey.com/industries / financial-services / our-insights / the-future-of-private-banking-in-europe-preparingfor-accelerated-change (accessed on 12 May 2021).

Barmuta, Karine, Vadim Ponkratov, Maksim Maramygin, Nikolay Kuznetsov, Vitali Ivlev, and Marina Ivleva. 2019. Mathematical model of optimizing the balance sheet structure of the Russian banking system with allowance for the foreign exchange risk levels. Entrepreneurship and Sustainability Issues 7: 484-97. [CrossRef]

Bawankule, Bhushan, and Arti Chandani. 2020. Omnichannel: An empirical analysis among Indian retail banking customers. International Journal of Modern Agriculture 9: 1454-75.

Berry, Leonard L., Lewis P. Carbone, and Stephan H. Haeckel. 2002. Managing the total customer experience. MIT Sloan Management Review 43: 85-89.

Boateng, Sheena Lovia. 2019. Online relationship marketing and customer loyalty: A signaling theory perspective. International Journal of Bank Marketing 37: 226-40. [CrossRef]

Boonlertvanich, Karin. 2019. Service quality, satisfaction, trust, and loyalty: The moderating role of main-bank and wealth status. International Journal of Bank Marketing 37: 278-302. [CrossRef]

Cahyadi, Afriyadi, and Róbert Magda. 2021. Digital leadership in the economies of the G20 countries: A secondary research. Economies 9: 32. [CrossRef]

Chan, Chun Kwong, Yulin Fang, and Huifang Li. 2020. Relative advantage of interactive electronic banking adoption by premium customers: The moderating role of social capital. Internet Research 30: 357-79. [CrossRef]

Chylinski, Mathew, Jonas Heller, Tim Hilken, Debbie Isobel Keeling, Dominik Mahr, and Ko de Ruyter. 2020. Augmented reality marketing: A technology-enabled approach to situated customer experience. Australian Marketing Journal 28: 374-84. [CrossRef]

Daoud, Rachid Ait, Abdellah Amine, Belaid Bouikhalene, and Rachid Lbibb. 2015. Customer segmentation model in E-commerce using clustering techniques and LRFM model: The case of online stores in Morocco. International Journal of Computer, Electrical, Automation, Control and Information Engineering 9: 2000-10.

Dew, R., and C. Allen. 2020. Customer Experience. How to Take Your Business to the Next Level. Moscow: LLC "Alpina Publisher", p. 290.

Dholakia, Utpal M., Barbara E. Kahn, Randy Reeves, Aric Rindfleisch, David W. Stewart, and Earl L. Taylor. 2010. Consumer behavior in a multichannel, multimedia retailing environment. Journal of Interactive Marketing 24: 86-95. [CrossRef]

Ding, Shuiping, Jie Lin, and Zhenyu Zhang. 2021. The influences of consumer-to-consumer interaction on dissatisfactory consumers' repetitive purchases in network communities. Sustainability 13: 869. [CrossRef]

Donati, Giovanni. 2020. Wealth Management \& Private Banking: Market Overview Q3 2020. Available online: https://www. boyden.com/de/media / wealth-management-and-private-banking-market-overview-q3-2020-18572341/index.html?page=2 (accessed on 12 May 2021).

Drummond, Conor, Thomas O'Toole, and Helen McGrath. 2020. Digital engagement strategies and tactics in social media marketing. European Journal of Marketing 54: 1247-80. [CrossRef]

Ershova, Alena Viktorovna, Dmitry Grigorievich Rodionov, Evgenii Alexandrovich Konnikov, and Olga Anatolyevna Konnikova. 2021. A systematic analysis of banks attractiveness for VIP-segment consumers within the digital information environment. Economic Sciences 194: 60-73.

Euromoney. 2020. Panel III: BRICS Private Banking Roundtable. Available online: https://www.euromoney.com/global-privatebanking-and-wealth-management-virtual-event-2020/panel-iii-brics (accessed on 12 May 2021).

Fader, P., and S. Thoms. 2021. Customer Centricity. Consumer Relations in the Digital Age. Moscow: LLC "Alpina Publisher", p. 190.

Fang, Yulin L., Israr Qureshi, Heshan Sun, Patrick McCole, Elaine Ramsey, and Kai H. Lim. 2014. Trust, satisfaction, and online repurchase intention: The moderating role of perceived effectiveness of e-commerce institutional mechanisms. MIS Quarterly 38: 407-27. [CrossRef]

Frank, R. G. 2020. Premium Banking in Russia 2020. Increasing Business Efficiency, Searching for a Digital Premium Model. Available online: https:/ frankrg.com/wp-content/uploads/2020/10/ee4c7e6dd138.pdf (accessed on 12 May 2021). 
Frasquet-Deltoro, Marta, Alejandro Molla-Descals, and Maria-Jose Miquel-Romero. 2021. Omnichannel retailer brand experience: Conceptualization and proposal of a comprehensive scale. Journal of Brand Management 28: 388-401. [CrossRef]

Furnival, Ariadne Chloe, Marcos Teruo Ouchi, and Euzébio Luiz Pinto. 2012. The "mystery shopping" technique used as a tool of service assessment in public libraries: A Brazilian experience involving Biblioteconomy undergraduates. Revista Interamericana de Bibliotecologia 35: 27-38.

Garzaro, Daniela Menezes, Luís Fernando Varotto, and Samara de Carvalho Pedro. 2021. Internet and mobile banking: The role of engagement and experience on satisfaction and loyalty. International Journal of Bank Marketing 39: 1-23. [CrossRef]

Gentile, Chiara, Nicola Spiller, and Giuliano Noci. 2007. How to sustain the customer experience: An overview of experience components that co-create value with the customer. European Management Journal 25: 395-410. [CrossRef]

Grewal, Dhruv, Julie Baker, Michael Levy, and Glenn B. Voss. 2003. The effects of wait expectations and store atmosphere evaluations on patronage intentions in service-intensive retail stores. Journal of Retailing 79: 259-68. [CrossRef]

Grohmann, Bianca, Eric R. Spangenberg, and David E. Sprott. 2007. The influence of tactile input on the evaluation of retail product offerings. Journal of Retailing 82: 237-45. [CrossRef]

Hickman, Ellie, Husni Kharouf, and Harjit Singh Sekhon. 2020. An omnichannel approach to retailing: Demystifying and identifying the factors influencing an omnichannel experience. International Review of Retail Distribution and Consumer Research 30: 266-88. [CrossRef]

Hoehle, Hartmut, Eusebio Scornavacca, and Sid Huff. 2012. Three decades of research on consumer adoption and utilization of electronic banking channels: A literature analysis. Decision Support Systems 54: 122-32. [CrossRef]

Ieva, Marco, and Cristina Ziliani. 2018. Mapping touchpoint exposure in retailing: Implications for developing an omnichannel customer experience. International Journal of Retail E Distribution Management 46: 304-22.

Ivashkova, Natalia I. 2016. Omnichannel marketing in the conditions of digitalization. In Economics in a Changing World: Collection of Scientific Articles. Kazan: Kazan Federal University, pp. 213-15.

Jacob, Steve, Nathalie Schiffino, and Benjamin Biard. 2018. The mystery shopper: A tool to measure public service delivery? International Review of Administrative Sciences 84: 164-84. [CrossRef]

Karpova, Svetlana V., I. V. Rozkov, and I. K. Zakharenko. 2019. Study of factors determining consumer behavior in the digital sphere. Problems of the Modern Economy 4: 85-88.

Karsh, Sharif Abu, and Yusuf Abufara. 2020. The new era of financial technology in banking industry. Journal of Southwest Jiaotong University 55: 1-13. [CrossRef]

Klaus, Philipp, and Stan Maklan. 2007. The role of brands in a service-dominated world. Journal of Brand Management 15: 115-22. [CrossRef]

Klaus, Philipp, and Stan Maklan. 2013. Towards a better measure of customer experience. International Journal of Market Research 55: 227-46. [CrossRef]

Komulainen, Hanna, and Saila Saraniemi. 2019. Customer centricity in mobile banking: A customer experience perspective. International Journal of Bank Marketing 37: 1082-102. [CrossRef]

Kotler, Philip, Hermawan Kartajaya, and Iwan Setiawan. 2016. Marketing 4.0: Moving from Traditional to Digital. Hoboken: John Wiley \& Sons.

Laukkanen, Tommi, Suvi Sinkkonen, Pekka Laukkanen, and Marke Kivijarvi. 2008. Segmenting bank customers by resistance to mobile banking. International Journal of Mobile Communications 6: 309-20. [CrossRef]

Lee, Sangjae, and Kun Chang Lee. 2020a. Comparative study of service quality on VIP customer satisfaction in Internet banking: South Korea case. Sustainability 12: 6365. [CrossRef]

Lee, Sang M., and Don Hee Lee. 2020b. Untact: A new customer service strategy in the digital age. Service Business 14: 1-22. [CrossRef]

Manivannan, Anand Shankar, and Preethi Sarah JP. 2018. Social media marketing and ghost shopping approach: A new business tool. International Journal of Mechanical Engineering and Technology 9: 181-89.

Marriott, Hannah R., and Michael D. Williams. 2018. Exploring consumers perceived risk and trust for mobile shopping: A theoretical framework and empirical study. Journal of Retailing and Consumer Services 42: 133-46. [CrossRef]

Montazemi, Ali Reza, and Hamed Qahri-Saremi. 2015. Factors affecting adoption of online banking: A meta-analytic structural equation modeling study. Information E Management 52: 210-26.

Naylor, Gillian, Susan Bardi Kleiser, Julie Baker, and Eric Yorkston. 2008. Using transformational appeals to enhance the retail experience. Journal of Retailing 84: 49-57. [CrossRef]

Nikumanesh, Esmaeil, and Amir Albadvi. 2014. Customer's life-time value using the RFM model in the banking industry: A case study. International Journal of Electronic Customer Relationship Management 8: 15-30. [CrossRef]

Nohutlu, Zeynep Didem, Basil G. Englis, Aard J. Groen, and Efthymios Constantinides. 2021. Customer co-creation experience in online communities: Antecedents and outcomes. European Journal of Innovation Management. [CrossRef]

Orlova, M., E. Kazanova, and E. Nebesnaya. 2020. Approaches to integrating customer experience in marketing management of a service organization. Marketing in Russia and Abroad 2: 69-75.

Oyner, Olga Konstantinovna, and Sergey P. Kazakov. 2019. Behavioral and psychographic segmentation as a tool to improve the consumer experience. Economy Business Banks 12: 46-53.

Ozdemir, Sena, and Paul Trott. 2009. Exploring the adoption of a service innovation: A study of internet banking adopters and non-adopters. Journal of Financial Services Marketing 13: 284-90. [CrossRef] 
Panteleeva, E. K., F. A. Galitsky, and E. B. Shamiryan. 2017. Drivers of consumer loyalty to online stores: A study of the influence of consumer experience on customer loyalty. Clearing and Customer Portfolio Management 2: 142-57.

Parasuraman, A. Parsu, Valarie A. Zeithaml, and Leonard L. Berry. 1985. A conceptual model of service quality and its implications for future research. Journal of Marketing 49: 41-50. [CrossRef]

Parasuraman, A. Parsu, Valarie A. Zeithaml, and Leonard L. Berry. 1988. SERVQUAL-A multiple-item scale for measuring consumer perceptions of service quality. Journal of Retailing 64: 12-40.

Parasuraman, A. Parsu, Valarie A. Zeithaml, and Arvind Malhotra. 2005. E-S-QUAL: A multiple-item scale for assessing electronic service quality. Journal of Service Research 7: 213-310. [CrossRef]

Parise, Salvatore, Patricia J. Guinan, and Ron Kafka. 2016. Solving the crisis of immediacy: How digital technology can transform the customer experience. Business Horizons 59: 411-20. [CrossRef]

Park, HyunJee, and Sang Ok Choi. 2019. Digital innovation adoption and its economic impact focused on path analysis at national level. Journal of Open Innovation: Technology, Market, and Complexity 5: 56. [CrossRef]

Payne, Elizabeth H. Manser, James Peltier, and Victor A. Barger. 2021. Enhancing the value co-creation process: Artificial intelligence and mobile banking service platforms. Journal of Research in Interactive Marketing 15: 68-85. [CrossRef]

Phan, Thuy Chung, Marc Oliver Rieger, and Mei Wang. 2019. Segmentation of financial clients by attitudes and behavior: A comparison between Switzerland and Vietnam. International Journal of Bank Marketing 37: 44-68. [CrossRef]

Pinar, Musa, Zeliha Eser, and Sandy Strasser. 2010. Using Mystery Shopping to compare the service quality of banks in Turkey. Services Marketing Quarterly 31: 1-26. [CrossRef]

Pino, Giovanni, Cesare Amatulli, Rajan Nataraajan, Matteo De Angelis, Alessandro M. Peluso, and Gianluigi Guido. 2020. Product touch in the real and digital world: How do consumers react? Journal of Business Research 112: 492-501. [CrossRef]

Rawson, Alex, Ewan Duncan, and Conor Jones. 2005. The truth about customer experience. Harvard Business Review. Available online: https:/ / hbr.org/2013/09/the-truth-about-customer-experience (accessed on 12 May 2021).

Rincón, Alfredo Guzmán, Ruby Lorena Carrillo Barbosa, Ester Martín-Caro Álamo, and Belén Rodríguez-Cánovas. 2021. Sustainable consumption behaviour in Colombia: An exploratory analysis. Sustainability 13: 802. [CrossRef]

Saha, K. 2009. Mystery shopping: A marketing research tool to measure customer satisfaction. Journal of Business and Economic Issues 1: 86-91.

Schwager, Andre, and Chris Meyer. 2007. Understanding customer experience. Harvard Business Review. Available online: https: / / hbr.org/2007/02/understanding-customer-experience (accessed on 12 May 2021).

Shaikh, Aijaz A., Richard Glavee-Geo, and Heikki Karjaluoto. 2017. Exploring the nexus between financial sector reforms and the emergence of digital banking culture-Evidences from a developing country. Research in International Business and Finance 42: 1030-39. [CrossRef]

Shaikh, Aijaz A., Majed D. Alharthi, and Hawazen O. Alamoudi. 2020. Examining key drivers of consumer experience with (non-financial) digital services-An exploratory study. Journal of Retailing and Consumer Services 55: 102073. [CrossRef]

Shankar, Amit, and Charles Jebarajakirthy. 2019. The influence of e-banking service quality on customer loyalty: A moderated mediation approach. International Journal of Bank Marketing 37: 1119-42. [CrossRef]

Shin, Jae Woo. 2021. Mediating effect of satisfaction in the relationship between customer experience and intention to reuse digital banks in Korea. Social Behavior and Personality 49: e9753. [CrossRef]

Shin, Jae Woo, Ji Yeon Cho, and Bong Gyou Lee. 2020. Customer perceptions of Korean digital and traditional banks. International Journal of Bank Marketing 38: 529-47. [CrossRef]

Sia, Siew Kien, Christina Soh, and Peter Weill. 2016. How DBS bank pursued a digital business strategy. MIS Quarterly Executive 15: 105-21.

Solovieva, Dina Vitalievna, Daniil Aleksandrovich Savostin, and Anastasia Stanislavna Zemlyannaya. 2020. Emotional marketing as a concept of generation $\mathrm{Z}$ consumer experience management. Practical Marketing 7: 27-36.

Sousa, Rui, and Christopher A. Voss. 2006. Service quality in multichannel services employing virtual channels. Journal of Service Research 8: 356-71. [CrossRef]

Stankevich, Alina. 2017. Explaining the consumer decision-making process. Journal of International Business Research and Marketing 6: 7-14. [CrossRef]

Su, Ching-Shu, and Chen-Tsang (Simon) Tsai. 2014. The implication of Mystery Shopping program in chain restaurants: Supervisors' perception. Journal of Foodservice Business Research 17: 267-82. [CrossRef]

Szopiński, Tomasz Stanisław. 2016. Factors affecting the adoption of online banking in Poland. Journal of Business Research 69: 4763-68. [CrossRef]

Tarantola, Claudia, Paola Vicard, and Ioannis Ntzoufras. 2012. Monitoring and improving Greek banking services using Bayesian networks: An analysis of mystery shopping data. Expert Systems with Applications 39: 10103-11. [CrossRef]

Timokhina, Galina. 2019. Behaviour of high-income consumers: Results of research of the private banking services market in Russia. Upravlenets 10: 85-97. [CrossRef]

Timokhina, Galina, and Larisa Kapustina. 2017. Niche Marketing-Management Strategies of Russian Banks in the Private Banking Segment. Paper presented at the 11th International Days of Statistics and Economics, Prague, Czech Republic, September 14-16, pp. 1674-84. 
Umans, Timurs, Martin Kockum, Elin Nilsson, and Sofie Lindberg. 2018. Digitalisation in the banking industry and workers subjective well-being: Contingency perspective. International Journal of Health Management 11: 411-23. [CrossRef]

Vargo, Stephen L., and Robert F. Lusch. 2004. Evolving to a new dominant logic for marketing. Journal of Marketing 68: 1-17. [CrossRef]

Vatolkina, Natalia, Elena Gorbashko, Nadezhda Kamynina, and Olga Fedotkina. 2020. E-service quality from attributes to outcomes: The similarity and difference between digital and hybrid services. Journal of Open Innovation: Technology, Market, and Complexity 6: 143. [CrossRef]

Verhoef, Peter C., Scott A. Neslin, and Björn Vroomen. 2007. Multichannel customer management: Understanding the research shopper phenomenon. International Journal of Research in Marketing 24: 129-48. [CrossRef]

Verhoef, Peter C., Katherine N. Lemon, Ananthanarayanan Parasuraman, Anne Roggeveen, Michael Tsiros, and Leonard A. Schlesinger. 2009. Customer experience creation: Determinants, dynamics and management strategies. Journal of Retailing 85: 31-41. [CrossRef]

Voorveld, Hilde AM, Edith G. Smit, Peter C. Neijens, and AE Fred Bronner. 2016. Consumers' cross-channel use in online and offline purchases: An analysis of cross-media and cross-channel behaviors between products. Journal of Advertising Research 56: 385-400. [CrossRef]

Voss, Chris, Aleda V. Roth, and Richard B. Chase. 2009. Experience, service operations strategy, and services as destinations: Foundations and exploratory investigation. Production and Operations Management 17: 247-66. [CrossRef]

Wang, Yang, Sui Xiuping, and Qi Zhang. 2021. Can fintech improve the efficiency of commercial banks?-An analysis based on big data. Research in International Business and Finance 55: 101338. [CrossRef]

Weiber, Rolf, and Tobias Kollmann. 1998. Competitive advantages in virtual markets-Perspectives of "information-based marketing" in cyberspace. European Journal of Marketing 32: 603-15. [CrossRef]

Yoon, Cheolho. 2010. Antecedents of customer satisfaction with online banking in China: The effects of experience. Computers in Human Behavior 26: 1296-304. [CrossRef]

Yuen, Yee. 2013. Gender and age effect on acceptance of Internet banking: Cultural comparison between United States and Malaysia. International Journal of Business and Management 8: 1-11. [CrossRef]

Yuen, Yee Yen, Paul HP Yeow, and Nena Lim. 2015. Internet banking acceptance in the United States and Malaysia: A cross-cultural examination. Marketing Intelligence E Planning 33: 292-308.

Zhang, Yun, Qingxiong Weng, and Nan Zhu. 2018. The relationships between electronic banking adoption and its antecedents: A meta-analytic study of the role of national culture. International Journal of Information Management 40: 76-87. [CrossRef] 